\title{
Flood Resilience of Critical Infrastructure: Approach and Method Applied to Fort Lauderdale, Florida
}

\author{
Karin M. de Bruijn ${ }^{1, *}$, Carolina Maran ${ }^{2}$, Mike Zygnerski ${ }^{2}$, Jennifer Jurado ${ }^{2}$, Andreas Burzel ${ }^{1}$, \\ Claire Jeuken ${ }^{3}$ and Jayantha Obeysekera ${ }^{4, *}$ \\ 1 Deltares, 2600 MH Delft, The Netherlands; Andreas.Burzel@deltares.nl \\ 2 Environmental Planning and Community Resilience Division, Environmental Protection and Growth \\ Management Department, Broward County, Fort Lauderdale, FL 33301, USA; CMaran@broward.org (C.M.); \\ MZygnerski@broward.org (M.Z.); JJurado@broward.org (J.J.) \\ 3 Deltares USA Inc., Silver Spring, MD 20910, USA; claire.jeuken@deltares-usa.us \\ 4 Sea Level Solutions Center, Florida International University, Miami, FL 33199, USA \\ * Correspondence: karin.debruijn@deltares.nl (K.M.d.B.); jobeysek@fiu.edu (J.O.)
}

Received: 17 January 2019; Accepted: 6 March 2019; Published: 12 March 2019

check for updates

\begin{abstract}
In order to increase the flood resilience of cities (i.e., the ability to cope with flood hazards), it is also crucial to make critical infrastructure functions resilient, since these are essential for urban society. Cities are complex systems with many actors of different disciplines and many interdependent critical infrastructure networks and functions. Common flood risk analysis techniques provide useful information but are not sufficient to obtain a complete overview of the effects of flooding and potential measures to increase flood resilience related to critical infrastructure networks. Therefore, a more comprehensive approach is needed which helps accessing knowledge of actors in a structured way. Fort Lauderdale, Florida, United States has suffered from flood impacts, especially from disruptions in critical infrastructure. This paper shows how shared insight among different sectors and stakeholders into critical infrastructure resilience and potential resilience-enhancing measures was obtained using input from these actors. It also provides a first quantitative indication of resilience, indicated by the potential disruption due to floods and the effect of measures on resilience. The paper contributes to the existing literature on resilience specifically by considering the duration of disruption, the inclusion of critical infrastructure disruption in flood impact analysis, and the step from resilience quantification to measures.
\end{abstract}

Keywords: resilience; flood risk management; critical infrastructure

\section{Introduction}

Many coastal and riverside cities face increasing flood hazards and impacts [1-4]. Compounding effects of sea level rise, increased frequency and severity of hurricanes, and intensive rainfall may lead to increased flood risks if no adaptation measures are taken. Also, urban growth and the increasing complexity and dependency on critical services such as water utilities, power supply, communication networks, and transportation require reconsideration of flood risk management strategies and adaptation planning.

Flood risk management plans and climate adaptation strategies focusing on flood risks are urgently needed for regions already experiencing increasing stresses and shocks. Generally, flood risk management strategies are developed based on information about flood risks and cost-benefit analyses. Although flood risk analysis could contain full economic analyses, consider many different types of impacts, and take into account recovery, in practice, often simplified approaches are applied, which have the following limitations [4]: 
- They do not include all types of impacts: They focus on monetary impacts which are directly linked to the flooding, such as damage to buildings and possessions, loss of income, or production losses in the flooded area. They neglect intangibles such as stress, health effects, and loss of personal belongings, and they do not fully take into account indirect effects, such as damage due to nonfunctioning infrastructure, image-loss.

- They do not look at the whole process of flooding: They consider the maximum flood depth and flow velocity, but do not provide knowledge on the succession of subevents during flooding and they do not include the behavior of individuals, businesses, and governments before, during, and immediately after a flood event [5].

- They may be applied per location and neglect spatial dependencies: One may assess flood probability, flood impacts, and the effect of measures per location without due consideration of effects on other locations. However, in reality, some measures will also affect flood risks elsewhere. Raising embankments, for example, will increase flood risks across the river and downstream.

- They result in aggregated information and often do not reveal the contribution of various factors/events: In most flood risk management documents, only a single risk number is given, which is the expected annual damage, or alternatively, the fact that a property is in or out of the once-in-a-hundred-years flood zone. The effects of more extreme events are rarely described.

- They are often not linked to other developments in the area: The flood risk analysis and measure selection is often done by flood risk engineers or water authorities and not shared with other actors in the flood-prone area. Therefore, other developments may be missed and the outcomes may not be understood or agreed upon by others.

Measures based on such approaches usually focus on flood protection or spatial planning. The effects of floods on critical infrastructure (CI) and potential cascading effects are often not included in flood impact analyses, although they can impact society severely [6]. Disruptions in power supply, for example, resulted in disruptions in critical services which caused serious business interruption [7-9]. Disruptions in transport and communication networks also hamper emergency management and recovery after flood events and lengthen the period during which communities are affected. There are some studies which look at flood impacts on CI, but they are generally mono-sectoral and focus on, for example, roads [10] and they do not look at cascading effects, dependencies, or on the effects of disruptions on society [6]. After severe events such as the 2007 floods in the United Kingdom, CI flood disruption was studied [7,8], but in most flood risk analyses or climate change effect studies, it is overlooked.

Since flood impacts on CI are often not assessed, $\mathrm{CI}$ is also overlooked in the portfolio of adaptation measures. Because the functioning of $\mathrm{CI}$ is critical for communities, it should also be part of the adaptation strategies to increase communities' resilience. Pant et al. [6] acknowledged this and looked at direct and indirect risks, which they defined as the number of customers affected directly or indirectly by outages of CI networks. They developed a method to quantify flood impacts to CI based on reliable spatial data of the networks. However, they did not consider the duration of interruptions of CI failures nor did they look at measures or strategies to reduce impacts.

To develop adaptation strategies which do consider CI services, understanding of the urban system, causes of impacts, chains of events, and interdependencies is needed and sharing of this understanding with all relevant actors is crucial [11,12]. Adding analysis of system interrelations; considering beyond-design events; looking at which crucial services must continue functioning even if some components are flooded; analyzing recovery after a flood event; and trying to remain resilient into the future even when the population increases, major storms and rainfall intensify, and the sea level rises, fits with what is referred to as a "resilience approach" [4]. To obtain a widely supported joint problem definition and strategy, many stakeholders need to be involved. This co-production approach requires a planning process supported by tools which allow for integration of information from different disciplines, interaction between different stakeholders across different sectors, joint fact finding, switching between different spatial and time scales, and easy visualization and communication. 
This paper adopts a resilience approach; analyzes flood impacts on CI elements, critical functions, and society and their duration; and then makes a first attempt to go from resilience analysis to resilience-enhancing measures.

The area of study is Fort Lauderdale, Broward County in South Florida (United States). Recently, this area was hit hard by extreme events, including hurricanes. Flood hazards are expected to increase further in future due to sea level rise, increasing frequency and strength of major hurricanes, and increasing rainfall intensities. Since this county has dense, urbanized areas with a complex physical and societal system, governments cannot prevent disasters by themselves and need strong collaboration of various stakeholders and citizens. In this project, a team consisting of researchers, local governments, water management agencies, and CI operators and managers worked together to increase understanding of flooding events and consequences and to develop a shared vision of both the problem and solutions. The concept of resilience is used as guidance to identify potential mitigation and adaptation measures. To obtain the best information in a structural and visual way, the CIrcle tool [13] and a storyline approach [14] were used and the bowtie scheme [15] was adopted (see descriptions in Section 2).

The paper is based on the outcomes of the CIFre project. The CIFre project used a combination of methods which support stakeholders to deliver inputs in a structural way in order to identify the possible chains of events, vulnerable critical infrastructure, and cascading effects and to explore and identify potential adaptation measures. This paper explains the approach; provides the collected information on flood hazards, direct and indirect impacts, and potential measures; and uses the information to quantify the current and future resilience of Fort Lauderdale.

\section{Approach}

\subsection{Overview of the Resilience Approach Adopted}

The resilience approach has gained attention, since it covers aspects which are often overlooked in more traditional risk approaches. In this paper, the National Academy's definition of resilience is adopted: "resilience is the ability to prepare and plan for, absorb, recover from and more successfully adapt to adverse events" [16]. Since this paper focuses on floods, the definition here is specified to flood resilience: "the ability of a system to cope with flood hazards now and in the future". In general, resilient systems need to have the ability to (see Figure 1):

1. prevent frequent events from causing negative impacts;

2. mitigate impacts of rare events so they do not become disastrous;

3. easily recover from impacts;

4. learn from events, adapt to changes, and maintain their ability to cope with disturbances also in the future.

Many different resilience definitions have been provided in the literature (for an overview, see, e.g., [16]). Most of them do acknowledge that resilience has to with systems and their reaction to disturbances and with recovery ability [4]. However, not all researchers include all four abilities in the concept of resilience. The first ability is sometimes linked to 'resistance' and the fourth to 'adaptability'. This difference in wording does not change the idea of the need to have those four abilities to cope with disturbances and trends to remain functioning now and in the future. Others, such as [17], focus on adaptability and transformability as a key to resilience. Here, we acknowledge the need for adaptability, but we focus on the other three abilities in order to evaluate the need for adaptation and to support learning. 


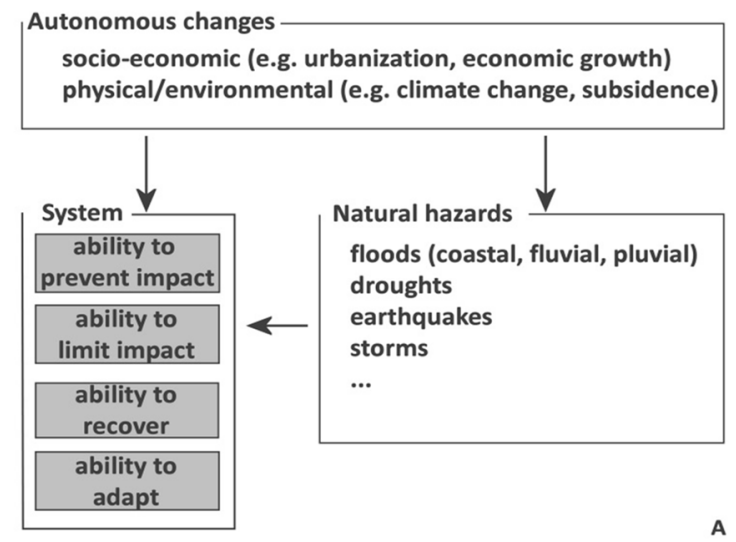

Figure 1. The four abilities which systems need to cope with flood hazards.

Resilience is a characteristic of a system. In this paper, the system is the city of Fort Lauderdale and its communities. To increase this city's resilience, the study focused on the CI and the effects of flood-related interruptions in CI on society. This resilience approach adds to the more standard flood risk and climate change adaptation approaches.

To support decision-making on resilience measures, resilience indicators are needed. These indicators translate resilience into a measurable concept and provide a "lens through which complexities of cities as socio-ecological systems can be better understood" [18]. They can be used to determine baseline conditions and the effectiveness of measures, as well as to measure progress. Many resilience assessment frameworks are available. For an overview, see [18]. To measure the current resilience of a system, two approaches are possible: one can either look at the system's behavior and quantify the disturbance or the recovery for a wide range of events, or alternatively, assess the presence of system characteristics which contribute to resilient behavior.

In the first approach, the response of a system to events is studied. Figure 2a shows the reaction of a system state to a disturbance. Insight into the resilience of the system can be obtained by describing the reaction threshold (i.e., the threshold above which events cause negative impacts), the amplitude A of those negative impacts, and the recovery rate. Figure $2 b$ shows responses to many events with increasing severity. In this example, frequent events do not cause disruption, while more rare events cause small disruptions and very rare events disrupt many persons for many days. If this system would be made more resilient, the curve would go down and the steep rise would become less steep and move to the right [19].

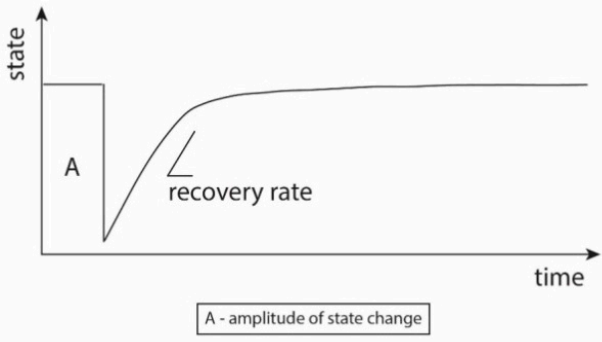

(a)

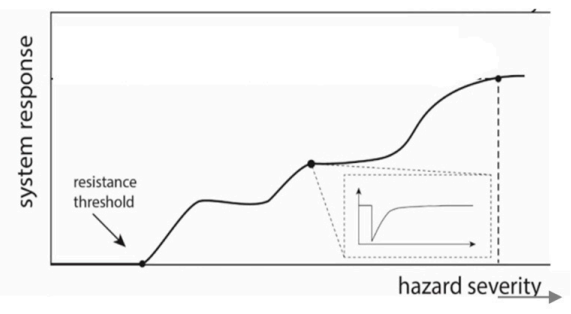

(b)

Figure 2. System response to a single shock (a) and as a function of disturbance magnitude (hazard severity) (b) (adapted from [19]).

Adopting the second approach implies that an indication of a system's resilience is obtained by looking at properties of society which are needed to be resilient, such as having redundancy in CI networks and the availability of capital which enhances a fast recovery. Classifications of such characteristics are provided by, among others, the 100 Resilience City Framework [20] and 
the documents of [18]. For different types of systems, different properties and classifications are available (e.g., a river basin, city, or CI network), since a different set of characteristics is defined as being crucial for the system to show resilient behavior. Examples of such properties related to $\mathrm{CI}$ are redundancy, flexibility, and robustness [19]. Next to these, general characteristics related to governance and economic and organizational characteristics are relevant for implementing measures, preparing and responding, and learning and adapting. Examples of such characteristics are resourcefulness, organizational/collaborative capacities, and foresight abilities.

We adopted the first approach (looking at a system's response to disturbances) in order to gain insight into the system's resilience. To quantify the resilience, the indicator proposed by [19] was used: "person disruption days". This indicator is calculated both for an event in the current system and in a future system in which measures have been implemented. This results in an indication of current resilience and the effect of measures on that resilience.

We used the second approach to identify measures which contribute to resilience; we looked at the system properties needed to show resilient behavior and defined measures for those. Similar to [19], here, the system properties of robustness, flexibility, and redundancy were also used. A system is robust if it can withstand the impacts of hazard events without significant damage or loss of function. Examples of measures that increase robustness are: a flood wall around a transformation station, raising the elevation of a highway or a critical junction in a highway, and raising or flood-proofing the location where the power supply enters the communication tower to enable these elements to withstand larger water depths. A redundant system has spare capacity or backup systems in order to accommodate disruption or damage to one part of the system. Redundancy measures include those measures which add backups to the system at crucial links, such as another road or a circular power supply network, so that there are two ways to reach each point. A flexible system can change, evolve, and adapt in response to changing circumstances, or its operation can change. Measures which make operation more flexible are, for example: enabling the switch to other existing roads or suppliers, expediting processes of reconfiguring existing processes and traffic routes, or ensuring that it is easy to change the mode of transport (e.g., from roads to ships). The effect of the different types of measures on the disruption for events with increasing severity is schematically shown in Figure 3. In that figure the blue line is the reference line, while the red line shows the impacts for the system after applying robustness measures such as raising a structure: the threshold of events which do not cause impacts, is increased compared to the reference system. The green line represents a system in which redundancy and flexibility measures are applied: impacts are reduced compared to those in the reference system.

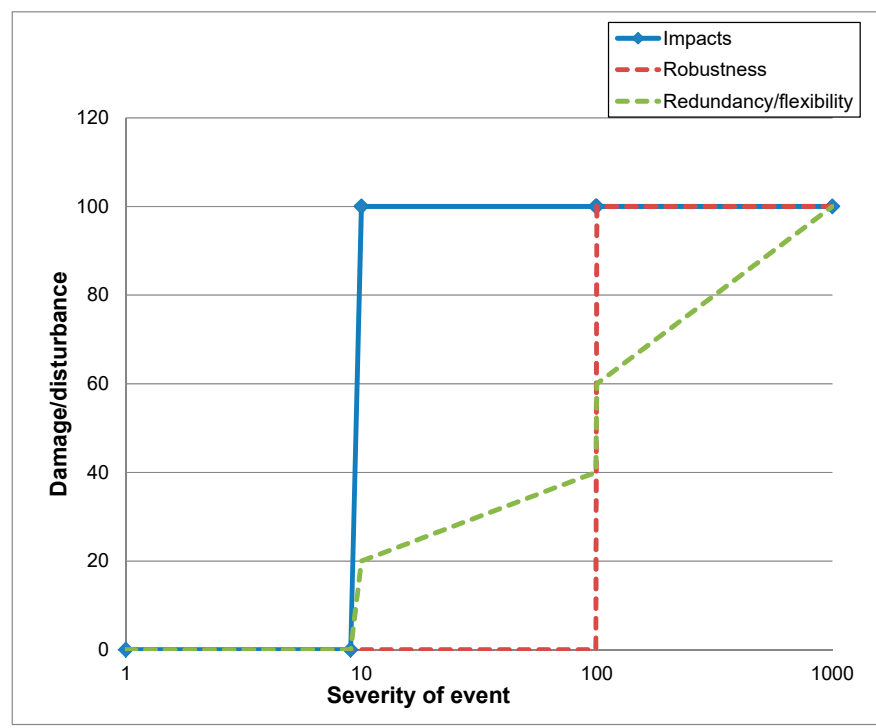

Figure 3. Severity-disruption relationship for a reference system and a system with added robustness, redundancy, and flexibility. 


\subsection{Steps Taken in the Case Study}

The project did not include all aspects of the area and society of Fort Lauderdale in the resilience analysis but focused on the resilience of the $\mathrm{CI}$ and its functions. The project applied a participatory approach to carry out five steps in two workshops. The five steps were based on [11]:

1. System exploration: Collect information on the:
a. flood hazard (type of hazards, frequency, resulting flood processes and patterns),
b. exposure (CI networks, their characteristics and dependencies (using CIrcle)),
c. flood impacts (past events, impacts of disruption of CI services on society), and
d. drelevant stakeholders and actors.

2. Storyline selection and elaboration: Select a storyline and walk through the chain of events in a workshop together with stakeholders. Consider actions just before, during, and after the event.

3. Resilience assessment.

4. Identifying potential adaptation measures (using the bowtie scheme).

5. Quantify future resilience and discuss the effect of measures.

In the first workshop, methods were shared and data was gathered on CI presence and interdependencies by using the CIrcle tool (step 1). Based on the hazard analysis done in step 1, the project team selected a severe but realistic event: the once-in-a-hundred years, three-day rainfall event, as there may be in 2060, and developed the storyline for that (step 2).

Then, there was a questionnaire sent to study awareness of issues and plans. Next, a second workshop was held in which the impacts of Hurricane Irma were discussed (as the hurricane happened after the first workshop). The resulting storyline and CIrcle diagram were presented and discussed, and promising mitigation and adaptation measures were identified using the bowtie scheme and evaluated (steps 4 and 5). Finally, the information gathered was completed and interviews were held to check and finalize the storyline, measures, and resilience quantification (steps 3 and 5).

The five steps and their application to Fort Lauderdale are explained in the next paragraphs. The workshop report [21] provides more details on the project and workshops.

\subsection{Data Input and Tools Used to Assess the Current Situation}

To assess resilience and identify potential measures, information was needed to answer the following questions:

- What area may become flooded and what are potential flood characteristics?

- What $\mathrm{CI}$ is present in the flood-prone area?

- What are the thresholds of damage of individual CI elements?

- If a particular CI element is damaged, does that cause the CI network to fail?

- If a CI service is disrupted, does that have cascading effects to other CI networks?

- What are the impacts on society of the CI disruptions?

- What is the overall resilience of communities related to CI disruptions?

- How can the resilience be increased?

To assess the hazard, a flood simulation was used (see Section 3.3). The scenario and the resulting inundation map were discussed with the stakeholders in the first workshop and considered plausible. The CI information for the selected area of study was obtained from open street maps, interviews with stakeholders, the literature, and, most importantly, during the two workshops. The information on cascading effects was obtained from the stakeholders in the workshops using the CIrcle tool and the storyline approach. Information on potential adaptation measures was obtained from the workshop participants in the second workshop using the bowtie diagram. The tools mentioned are described briefly below. 
The CIrcle tool, an online open touch table application [13,22], is used in participatory workshops to help stakeholders understand the complex and interdependent relations between CI systems. These relations, or causal links, can be investigated and rapidly visualized even within the context of data-poor environments. Within a workshop setting, first participants are asked to map out CI present in the area. A start can be made using information from open streetmap which can be corrected and completed by the participants. Next, for each CI network or service in the area the water depth threshold for direct damage is established as well as the effect of damage on a CI element to the functioning of the network. Then the cascading effects of disruptions in the network on other CI services are discussed. Finally, the impacts and duration of impacts on society are assessed [11].

The storyline approach means that a realistic and relevant hypothetical scenario is selected based on understanding of the system and that this scenario is discussed by stepping through time. First, the weather and water system effects are discussed; then the effects on physical systems as critical infrastructure are established; and, finally, the responses of emergency managers, authorities, critical infrastructure operators, communities, and citizens and their interactions are discussed [14]. This process shows what happens but also reveals the most important assumptions which must be verified. A storyline is like a story which can be paused to discuss the next step and its effects. It works as a communication tool for different actors from different backgrounds. A storyline has no probability and cannot be considered as a forecast. It is an example only to show what may happen and how actions affect others.

The bowtie method is a method that finds its origin in the oil and gas industry and helps to analyze critical events and associated risks. The method takes its name from the shape of the diagram, which looks like a man's bowtie (see Figure 4). The bowtie method is now used in many variants and fields [23]. It gives a visual summary of all plausible factors contributing to the risk scenario and supports the identification of control measures to mitigate the scenario or its consequences [24]. The method has been used to analyze CI and flood related risks before (see, e.g., the European H2020 Intact project [25]).

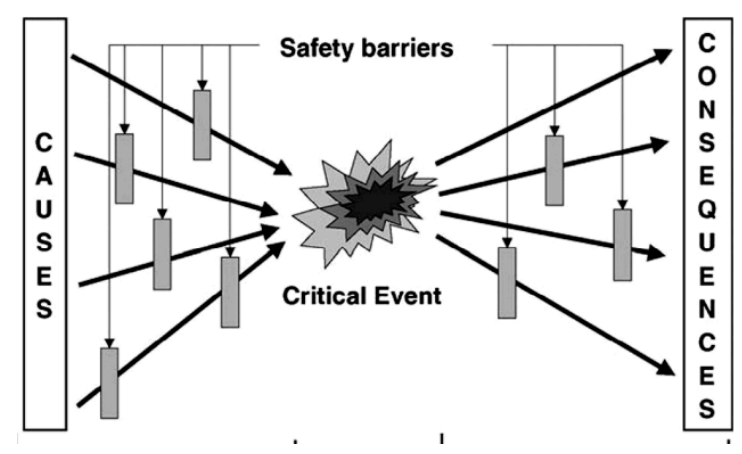

Figure 4. Generic bowtie scheme (source: [15]).

The bowtie method helps to identify potential measures (in the figure, they are identified as safety barriers). If the critical event is a flood, then at the left side, causes of flooding are shown (e.g., extreme rainfall), and in the grey boxes, measures can be entered which will prevent extreme rainfall to cause floods. At the right side, measures are entered which prevent floods to have consequences (e.g., if a flood consequence is power outage, a measure may be to raise the substation). After the first identification of many potential measures, an evaluation is needed to select feasible ones. Criteria such as cost, benefits (e.g., in terms of avoiding the number of cascades and/or disruption time), and feasibility (technical, support, capacity, financial/investment) may then be used. 


\section{Results: Resilience of the CI of Fort Lauderdale}

\subsection{Fort Lauderdale: Area Description}

Fort Lauderdale is a city located on the southeastern coast of Florida in Broward County. It has about 180,000 inhabitants [26]. The city has a major port and airport which are both very significant for businesses, industries, and tourism, including travels to the beaches, the Everglades swamps, and to the Florida metropole area. Two interstate routes-595 (from east to west) and 95 (from north to south)_ pass by Fort Lauderdale and are of large regional importance.

The area is low-lying, flat with organic or sandy soils overlying limestone, and very permeable. Groundwater levels are connected to the tides and rise fast during storm surges, which hampers drainage of storm water. The area has a sunny but wet climate with about $1540 \mathrm{~mm}$ of annual rain and an average temperature of $24.2^{\circ} \mathrm{C}$ [27].

The area is prone to tropical storms and hurricanes which bring strong winds and large quantities of rain. The rain is drained by canals and creeks which flow to the Atlantic Ocean. Most of the existing canal levels are controlled with water control structures and pumps. Floods occur after severe rainfall events and due to storm surges or high tides. The large tidal surges combined with wave action, antecedent high groundwater levels, and the heavy rainfall which accompanies these storms might cause severe inundations and the joint probability of occurrence of all these conditions needs to be assessed for current and future scenarios. The area has a long record of historic flood events [28]. The most recent severe ones in Broward County were the flooding due to Hurricane Irene in 2009, Storm Leslie in 2000, Hurricane Wilma in 2005, and Hurricane Irma in 2018. In these events, heavy rains and sustained winds caused widespread flooding and power outages and resulted in the isolation of communities [28].

In the future, flood hazards are expected to increase with the rising sea level and projections of more frequent storms and rainfall. Based on climate model runs conducted by the Center for Ocean-Atmospheric Prediction Studies (COAPS), a plausible future (2060-2069) precipitation scenario was selected with a 9\% increase in the annual average above the modeled annual average of 1990-1999 (1500 instead of $1400 \mathrm{~mm} /$ year) [29]. The sea level rise may be as large as 26.6-33.9 in. in 2060-2069 compared to the 1992 level (based on the USACE National Research Council Curve 3 (NCRC3)).

To prevent flooding, not only are drainage canals currently maintained and operated by water management districts and the local water-control districts, but seawalls have also been built by some waterfront residents. Large embankments are not feasible since water will flow underneath through the permeable subsoils. Furthermore, many properties rely upon insurances against flooding [28].

The area, like many developed regions, contains consolidated CI, such as roads, railroads, power supply networks, sewer systems, and communication networks. Furthermore, there are vulnerable spots such as hospitals and elderly homes (see Section 3.2). Many CI networks are vulnerable to floods or strong winds. Several smaller roads and exits of highways are flood-prone. An overview of vulnerable and critical roads is presented in [30]. Wind will affect transport alternatives on elevated roads. Power transformation stations, drinking water plants, and parts of the airport and port may become flooded, which might disrupt or hamper their functioning. The disruptions have cascading effects to other networks and aggravate the flood impacts on communities.

Since continuous socioeconomic development in the area is expected, as well as sea level rise and an increase in rainfall intensities, adaptation strategies have been formulated. Some strategies involve improved permitting requirements that will force new construction and major redevelopment to build to higher standards that consider climate change. Other adaptation measures focus on improved drainage, such as the transition to high-capacity conveyance systems and from gravity to pumped systems. These strategies thus primarily focus on land use planning, improving drainage infrastructure to comply with future rainfall quantities, coastal flood barriers, and insurances, but the effects and implications on CI have not yet been explicitly and comprehensively included. An example of research which has analyzed CI is a study on the vulnerability of roads to sea level rise in Miami-Dade 
County-Broward's southern neighbor county. Links between transport and other CI have not yet been studied, and this is what this project (CIFRE) intended to add.

\subsection{Vulnerability and Cascading Effects}

In the first workshop with the local authorities, water managers, and critical infrastructure operators, the participants identified the CI present in the flood-prone area. Based on the workshop results, information from literature, and expert judgement evaluations (see Table A1), a threshold for direct damage was established for each CI network. In the first workshop, also the effects of failure of a CI due to disruption of other CI types was assessed and illustrated by adding links in the CIrcle tool. Furthermore, the duration of the disruption of both the directly affected CI type and the cascading effects was estimated. Although the first workshop provided essential information, recovery durations were not completely covered. Therefore, the workshop outcomes were complemented with additional information obtained from stakeholders, by interviews and direct questions, and from literature.

The resulting CIrcle diagram and the table summarizing the information are provided in Figure 5 and Table A1. The figure is explained in the text below. The figure can be linked to different flood scenarios to gain insight into their consequences. In this project, they were linked with one specific flood scenario (see Section 3.1) and translated into a movie, which showed the disruption developing over time. This movie was used in the second workshop to support the discussion on the results and on potential measures.

As expected, Figure 5 shows that the power network is most critical and that disruptions in power supply affect almost all other CI networks. Most power-dependent CI systems have backup systems which allow them to continue functioning for about two to four days (e.g., communication services, storm water systems, drinking water plants, waste water facilities, and hospitals). In the selected scenario, the financial services, transportation, and drinking water supply will be affected but not fail completely. The rail and road transport is also affected by power disruptions since these will interrupt the functioning of signals, traffic lights, and bridges and might result in long delays. The power backup systems need fuel, which is usually stored at the port. If the port cannot operate or access roads to the port are flooded, then systems which need backup power will also become interrupted. Flight operation systems are usually not affected by power outages, as they have triple redundancy. However, power disruption affects the functioning of other systems relevant for the functioning of an airport, such as light, communication, luggage control, and financial systems.

Disruptions to the power supply may last long and will affect many people and businesses. Hurricane Irma affected about $68 \%$ of all residents and business accounts in Broward County. The repair took more than two weeks to be completed in many locations and was done according to a priority list. The priorities begin with the power station's own infrastructure (powerplants, substations, and major transmission lines), and the next priorities are critical facilities such as hospitals, police and fire stations, communications facilities, water treatment plants, and transportation providers. The remaining customers are prioritized based on the largest number of customers in the shortest amount of time, which includes major thoroughfares that host supermarkets, pharmacies, gas stations, and other needed community services.

Also, disruptions in road transport have many cascading effects, including highways, main roads, and local streets. The highways are usually elevated and not flood-prone. However, the exits to surface streets may be low in certain areas and become flooded. The roads are not only affected by flooding, but also by strong winds. Strong winds may result in debris and trees on the roads and fallen power and communication lines. Road transport is also affected indirectly: due to disruptions in the power supply, traffic lights may be out of function, which means at cross roads, traffic will be slow.

The power supply network, road network, airport, port, and drinking water plants are most likely to be affected directly by flood waters. They can resist water depths of a few inches (about $10 \mathrm{~cm}$ ) to one foot $(30 \mathrm{~cm})$ before they no longer function. The railroad, financial services, communication systems, storm water systems, emergency services, hospitals, and waste water systems are mainly 
affected by disruptions in other CI networks. A summary of the information obtained and added to the CIrcle tool is provided in Appendix A.

CI interruptions will seriously affect citizens, businesses, and also tourism, as we saw during Hurricane Irma.

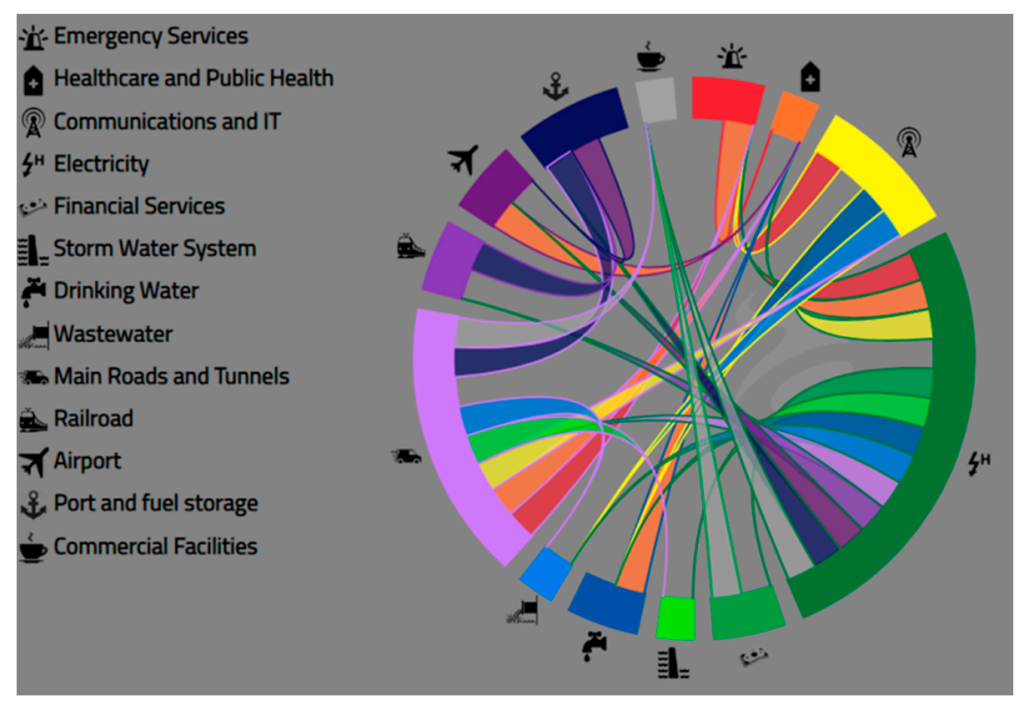

Figure 5. Illustration of the critical infrastructure (CI) dependencies in a CIrcle diagram.

\subsection{Storyline: 3 Day Extreme Rainfall Event (T100)}

\subsubsection{Selection of the Scenario of the Storyline}

To gain more insight into the future vulnerability and resilience of CI and society, a hypothetical but realistic scenario was used which links with current knowledge and practices: Policies are often based on the 100-year, 3-day extreme storm rainfall event, and this event is expected to increase in the future. The current 100-year return, 3-day rainfall is a design rainstorm event which is used to derive the official Broward 100-year flood elevation map to determine finished floor elevation. It is also the basis for the FEMA Flood Insurance Rate Map. Usually a 16-in. (406-mm) rainfall is associated with this event storm.

In this study, an event was analyzed which corresponded with a future severe storm and severe rainfall combined with a higher sea level. The rainfall we considered was $20 \mathrm{in}$. (508 $\mathrm{mm}$ ) in three days evenly distributed in space and following the standard rainfall distribution in time as recommended by the South Florida Water Management District's Environmental Resource Permit Applicant's handbook, volume II (1 October 2013). This event represented a 100-year, 3-day extreme storm event in 2060 [31]. The sea level considered lay $34 \mathrm{in}$. $(86 \mathrm{~cm})$ above the level of 1992. This increased sea level caused drainage to be hampered. The CI, population, and other exposure data were taken as it is today. This scenario allowed identification of exposed critical infrastructure in extreme events and analysis of potential impacts and measures; it was not meant to be understood as a prediction.

The flood inundation map corresponding with the severe rainfall was obtained in partnership with the USGS, using the MODFLOW Broward County Inundation model. This latest MODFLOW inundation model is integrated with a surface-water routing component and an urban hydrology component to offer a more detailed conceptualization of the surface-water/groundwater interactions between interception storage, overland flow, depression storage, and unsaturated zone storage [32]. The scenario was accepted among the participants as an extreme but realistic and relevant scenario to explore the current and future resilience of Fort Lauderdale. The chain of events before, during, and after this event are described below by discussing, respectively, the inundations, the effects on CI, and the responses of actors. 


\subsubsection{Before the Flooding}

In the hypothetical event, extreme rainfall and strong wind is forecasted. Canal levels are therefore lowered as much as feasible, the citizens are warned to prepare, and emergency responders also prepare themselves according to their protocols. The port prepares for the storm by removing all debris, securing potential flying hazards, and reducing the stacking height of containers to, at maximum, four containers for common materials and, at maximum, two for hazardous materials. Oceangoing vessels which are moored at anchor are warned and urged to get underway. Most vessels must depart before the storm hits. Ship-to-shore actions are planned so that they will not take place during landfall of the storm. Finally, all hazardous materials are removed from areas prone to flooding. A day before the storm hits, the port is closed for incoming cargo. The communities and families start preparing, supported by the Broward County emergency checklist [33]. Based on the information provided, they decide to stay or go to relatives in nonhazardous areas or shelters. Residents start preparing their houses, garages, protecting windows, and cleaning their gardens. Their actions strongly depend on their expectations of the severity of the event, which are based on the information provided by the government and their previous experience.

\subsubsection{During the Event}

The event raises sea water levels and brings 20 in. (about $65 \mathrm{~cm}$ ) of rain in just three days (see Figure 6). The strong winds make transport impossible and damage local power lines, houses, and cars. The rainfall also leads to inundations of inhabited areas and causes damage to CI. Figure 6 shows the flood map corresponding with the rainfall.

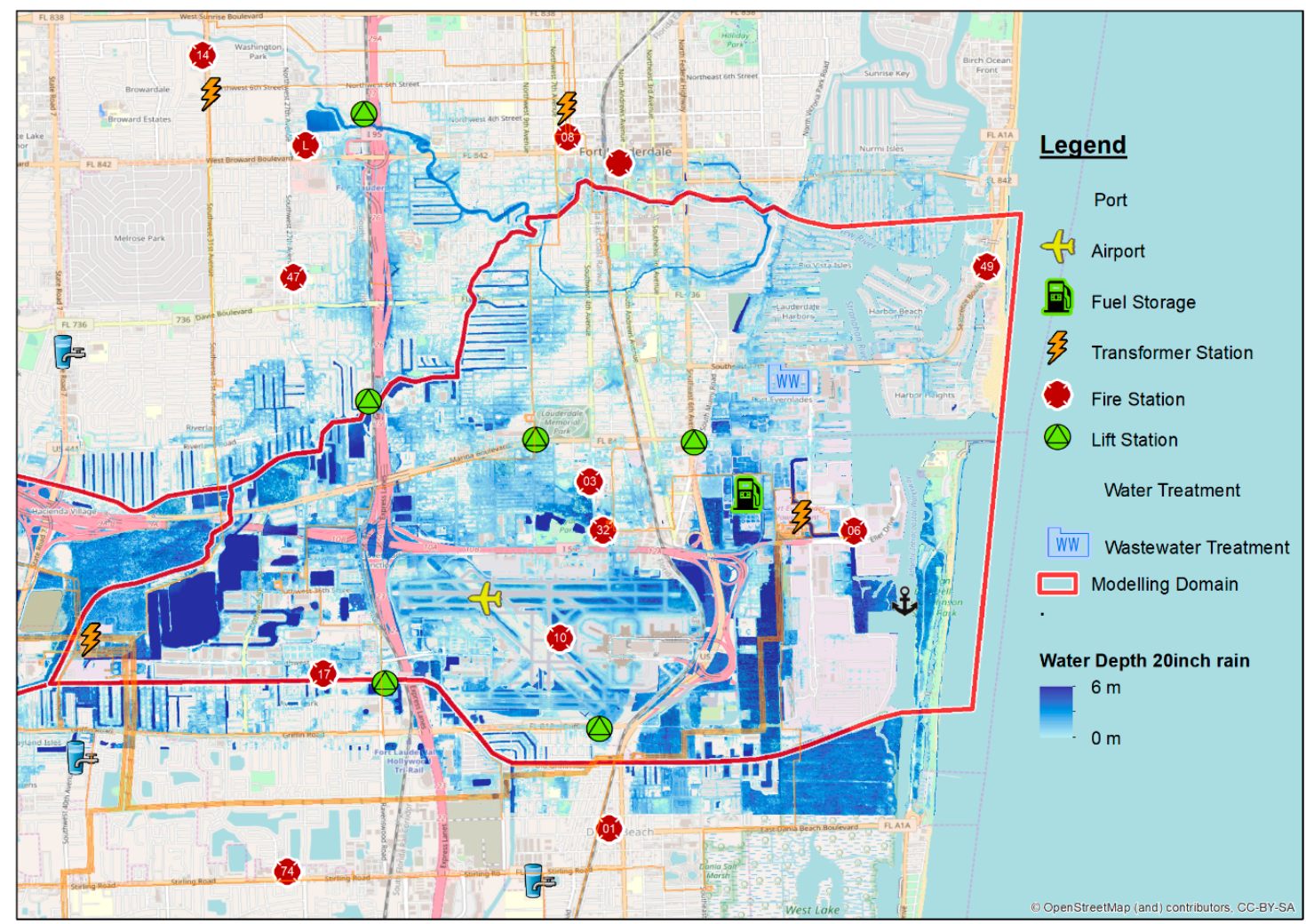

Figure 6. Flood depth map corresponding with the event.

The direct effects during the event are serious already: two substations become flooded with depths exceeding $30 \mathrm{~cm}$ in this scenario. Due to that event, about 15,000 houses do not have power anymore. Also nursing homes, a hospital, schools, and water treatment facilities are affected by the flood water directly. 
Roads are closed due to high winds and highway exits and smaller roads become flooded. Also, debris on roads makes them inaccessible. The port, hospital, and airport become inaccessible for several days due to roads being submerged by flood water, blocked by debris or fallen power lines, and trees. Some roads are washed away or collapsed and some are blocked by traffic incidents. On the remaining roads, traffic jams occur. Due to the blocked roads, people cannot not get food and supplies or go to their work, fallen power lines and broken communication lines cannot be repaired, and, also, people from outside the area, such as from the barrier islands, cannot evacuate their severely affected area.

The indirect effects are even more serious: due to the failure in the power network, communication also fails, traffic lights fail, and in some nursing homes, the air-conditioning fails. This may result in life-threatening situations, as was seen after Hurricane Irma, in which a nursing home in Broward lost air-conditioning, which led to the death of more than 10 elderly patients. The functioning of hospitals and health facilities is seriously affected due to the power disruption and lack of access to fuel, food, and supplies because of the flooded roads. There is limited fuel for their generators, and as soon as that is finished, they have no power. They cannot get fuel since roads are closed. Due to the interruption of the water treatment plants which have become flooded or are impacted by the disruptions in power and the lack of communication on this disruption, uncleaned water is released in the surface warning and peoples' health is at risk.

The emergency services are acting now and try to rescue the most vulnerable people and inform the others. The people in the flood-prone area stay indoors as long as the rain and wind are still strong and wait until the weather improves.

\subsubsection{After the Flood}

The floods and strong winds have caused billions of dollars of damages in Florida and Broward County. Also, Fort Lauderdale is hit hard. Thousands of people are working hard to repair the power supply, clear roads, and repair infrastructure. Sea ships come in after the storm and load fuel into the port. Fuel is transported again when roads are cleaned. The hospital and other vulnerable locations have power again within a few days. After about two weeks, the power supply is restored to everyone in this hypothetical scenario. People repair their houses and go back to business as usual within a few weeks to one month, except for the ones who lost relatives or friends.

\subsection{Resilience Assessment}

After the workshops and interviews, the research team captured the contributions of the stakeholders in an overview of the systems resilience. The outcomes must be considered as a first indication only and require further validation and improvements in follow-up projects. They serve as starting points for further discussions and are used here to illustrate the method and its potential outcomes. The effects of floods on communities and businesses were evaluated separately, although the businesses are crucial also for the communities. Table 1 provides an overview of the first rough indication of the effect on livability measured by the number of affected persons and the duration. The total summation of the products of the durations and the number of affected persons is provided as a total indication of disruption. In the future, weighing may be added to differentiate between different types of disturbances. Being without power might, for example, be more severe than facing a health risk because drinking water is not safe, while they are currently summed as if their disturbing effects are comparable. Table 1 provides the information and Table 2 gives the precise numbers used in the calculation. 
Table 1. Effect on livability of communities (source: based on the information provided, concrete assumptions were made and checked with experts).

\begin{tabular}{|c|c|c|c|c|}
\hline CI & Description & Impact Type & \# of Affected Persons & Duration \\
\hline Power supply & $\begin{array}{l}\text { No power, light, } \\
\text { air-conditioning }\end{array}$ & Direct & $\begin{array}{l}15,000 \text { houses } \times 3 \text { persons per house } \\
=45,000 \text { persons (based on Irma } \\
\text { impacts and expert judgement) }\end{array}$ & 3-14 days \\
\hline Communication & $\begin{array}{l}\text { No access to } \\
\text { information/assistance }\end{array}$ & $\begin{array}{l}\text { Indirect due to } \\
\text { power outage }\end{array}$ & $\begin{array}{c}45,000 \text { persons (similar to the ones } \\
\text { without power) }\end{array}$ & 3-14 days \\
\hline Road transport & Roads are closed & Direct & $\begin{array}{c}\text { First } 1 \text { day: all inhabitants }(180,000) \text {, } \\
\text { then } 10 \% \text {, after } 1 \text { week, very few } \\
\text { inhabitants. }\end{array}$ & $\begin{array}{c}1 \text { day complete, } 3 \\
\text { days severe, } 1 \text { week } \\
\text { serious }\end{array}$ \\
\hline $\begin{array}{l}\text { Emergency services } \\
\text { and health care }\end{array}$ & $\begin{array}{l}\text { Less access to } \\
\text { information and } \\
\text { responders, health } \\
\text { risks }\end{array}$ & $\begin{array}{l}\text { Indirect due to } \\
\text { closed roads and } \\
\text { power outages }\end{array}$ & Whole population at first, then $10 \%$ & $\begin{array}{l}3 \text { days, then } 1 \\
\text { week. }\end{array}$ \\
\hline Financial services & No cash & $\begin{array}{l}\text { Indirect due to } \\
\text { power outage }\end{array}$ & $\begin{array}{l}30 \% \text { of the cash machines affecting } \\
\begin{array}{c}30 \% \text { of the population }=0.3 \times 180,000 \\
=54,000\end{array}\end{array}$ & 3 days \\
\hline $\begin{array}{l}\text { Drinking water } \\
\text { supply }\end{array}$ & $\begin{array}{l}\text { Reduced livability, } \\
\text { health loss }\end{array}$ & Direct & Whole population: 180,000 & 3 days \\
\hline $\begin{array}{l}\text { Waste water } \\
\text { system }\end{array}$ & $\begin{array}{l}\text { Reduced livability, } \\
\text { health loss }\end{array}$ & $\begin{array}{l}\text { Indirect, loss of } \\
\text { communication, } \\
\text { power }\end{array}$ & $\begin{array}{l}\text { Rough estimation: } 10 \% \text { of the } \\
\text { population }\end{array}$ & 2 weeks \\
\hline $\begin{array}{l}\text { Storm water } \\
\text { system }\end{array}$ & $\begin{array}{l}\text { Additional local } \\
\text { flooding }\end{array}$ & $\begin{array}{l}\text { Indirect due to } \\
\text { power } \\
\text { interruptions }\end{array}$ & A few people locally & Several days \\
\hline $\begin{array}{l}\text { Commercial } \\
\text { facilities }\end{array}$ & $\begin{array}{l}\text { Shortage of food and } \\
\text { supplies }\end{array}$ & $\begin{array}{l}\text { Direct and indirect } \\
\text { due to power } \\
\text { supply, transport, } \\
\text { and financial } \\
\text { services } \\
\text { interruptions }\end{array}$ & $\begin{array}{c}70 \% \text { of businesses without power. } \\
\text { Assumption: also } 70 \% \text { of population } \\
\text { is affected }\end{array}$ & 3 days \\
\hline
\end{tabular}

Table 2. Disruption days calculation: affected persons times duration.

\begin{tabular}{cccc}
\hline Disruption Calculation & Affected & $\begin{array}{c}\text { Duration } \\
\text { (Days) }\end{array}$ & $\begin{array}{c}\text { Disruption Days } \\
\text { (Product) }\end{array}$ \\
\hline Power and/or communication outages & 45,000 & 7 & 315,000 \\
\hline Roads & 180,000 & 1 & 180,000 \\
18,000 & 2 & 36,000 \\
\hline Financial services outages & 54,000 & 7 & 378,000 \\
\hline Emergency and health & 180,000 & 3 & 540,000 \\
\hline Drinking water & 18,000 & 7 & 126,000 \\
\hline Waste water & 180,000 & 3 & 540,000 \\
\hline Commercial & 18,000 & 14 & 252,000 \\
\hline SUM & 126,000 & 3 & 378,000 \\
\hline
\end{tabular}

Table 3 provides the effects on businesses. Since the project has no information on the value and type of businesses, only a rough indication is provided here. Detailed analysis would require differentiation between businesses types, their contribution to the local economy, and employment within communities. 
Table 3. Most relevant business impacts.

\begin{tabular}{|c|c|c|c|c|}
\hline CI & Description & Impact Type & $\begin{array}{c}\text { \# of Affected Persons } \\
\text { (Workshop Report, Interviews) }\end{array}$ & Duration \\
\hline Power supply & $\begin{array}{l}\text { No power, light, } \\
\text { air-conditioning }\end{array}$ & Direct & $70 \%$ of all businesses & 3-7 days \\
\hline Communication & $\begin{array}{l}\text { No access to } \\
\text { information/assistance }\end{array}$ & $\begin{array}{l}\text { Indirect due to } \\
\text { power outage }\end{array}$ & $70 \%$ of all businesses & 3-7 days \\
\hline Road transport & Roads are closed & Direct & $\begin{array}{c}\text { First } 1 \text { day: all, then } 10 \% \text {, after } 1 \\
\text { week, very few (expert } \\
\text { judgement) }\end{array}$ & $1-7$ days \\
\hline $\begin{array}{l}\text { Emergency services } \\
\text { and health care }\end{array}$ & Less access to police & $\begin{array}{l}\text { Indirect due to } \\
\text { closed roads and } \\
\text { power outages }\end{array}$ & $100 \%$ at first, then $10 \%$ & $\begin{array}{l}3 \text { days, then } 1 \\
\text { week. }\end{array}$ \\
\hline Financial services & No cash & $\begin{array}{l}\text { Indirect due to } \\
\text { power outage }\end{array}$ & $\begin{array}{l}30 \% \text { of population and } \\
\text { businesses }\end{array}$ & 3 days \\
\hline $\begin{array}{l}\text { Commercial } \\
\text { facilities }\end{array}$ & $\begin{array}{l}\text { Shortage of food and } \\
\text { supplies }\end{array}$ & $\begin{array}{l}\text { Direct and indirect } \\
\text { due to power } \\
\text { supply, transport } \\
\text { interruptions }\end{array}$ & $\begin{array}{l}70 \% \text { for the first } 3 \text { days, } 30 \% \\
\text { after a week, then reducing fast. }\end{array}$ & 3 days \\
\hline $\begin{array}{l}\text { Airport, railroad, } \\
\text { and Harbor }\end{array}$ & $\begin{array}{c}\text { Closure or } \\
\text { delays/flight/boat } \\
\text { cancelations/impossibility } \\
\text { of getting supplies/fuel }\end{array}$ & $\begin{array}{l}\text { Direct and indirect } \\
\text { due to transport } \\
\text { and power } \\
\text { interruptions }\end{array}$ & $\begin{array}{l}\text { Not quantified: related to } \\
\text { number of passengers per day } \\
\text { and number of businesses } \\
\text { depending on } \\
\text { air-transport/port; also, health } \\
\text { risks may be considered. } \\
\text { Furthermore, image loss may } \\
\text { have significant impact on the } \\
\text { local economy. }\end{array}$ & $\begin{array}{c}3 \text { days, image loss } \\
\text { may affect area for } \\
\text { years }\end{array}$ \\
\hline
\end{tabular}

About $70 \%$ of all businesses are affected by the scenario and some in multiple ways. After seven days, $30 \%$ are still affected, mainly due to loss of supplies, disruptions in financial services, etc. Compared to $100 \%$ business operation, the loss indicator, which is the area between the $100 \%$ functioning line and the curve in Figure 7, is about $34 \%$. These numbers are partly based on assumptions and thus serve to illustrate the method and to provide an order of magnitude.

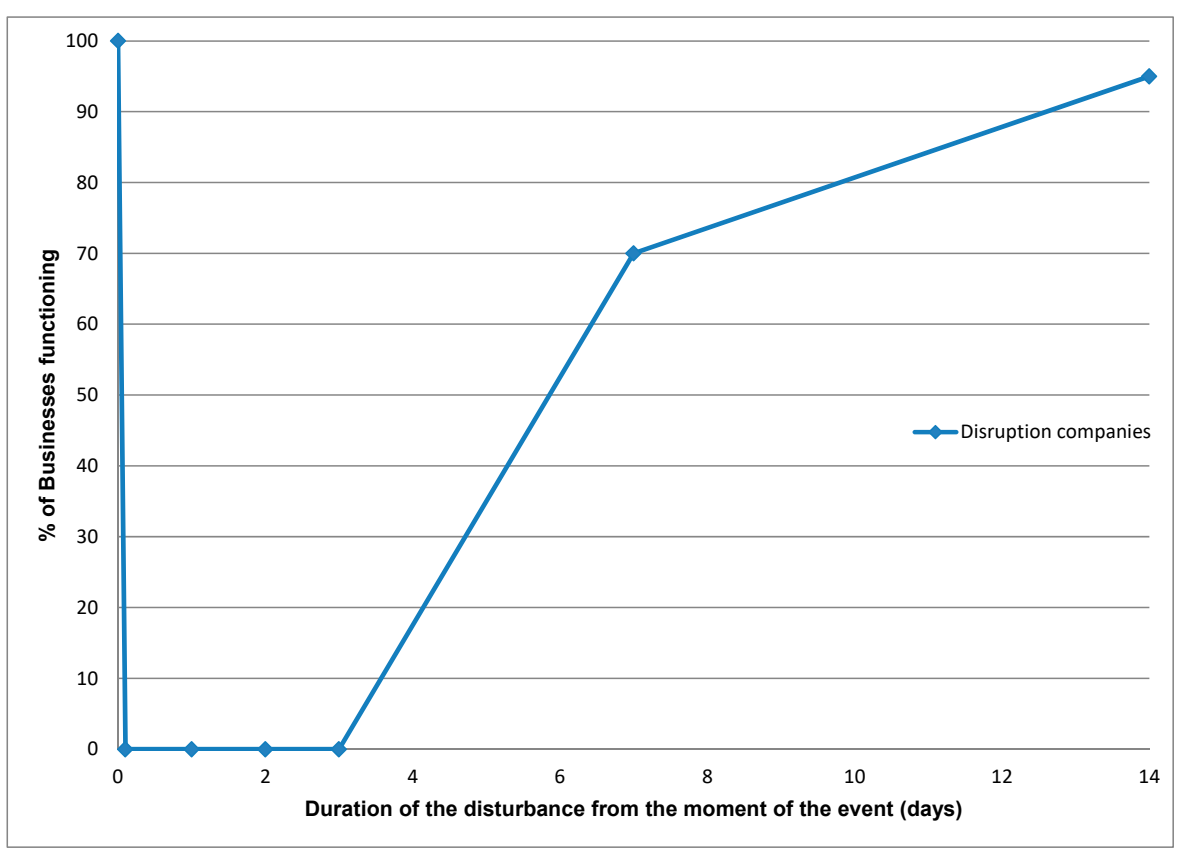

Figure 7. Disruption over time for the storyline scenario. The total disruption can be assessed by calculating the area between the $100 \%$ level and the blue curve. The total disruption is $34 \%$ of the total businesses functioning 


\section{Exploring Resilience Increasing Measures}

Bowtie schemes were used to show the cascading effects and link those to the two main disturbances (power outages and transport outages). Furthermore, adaptation measures related to the resilience characteristics of robustness, redundancy, and flexibility were discussed. The resulting bowtie schemes are shown in Figure 8 for electricity and Figure 9 for roads.

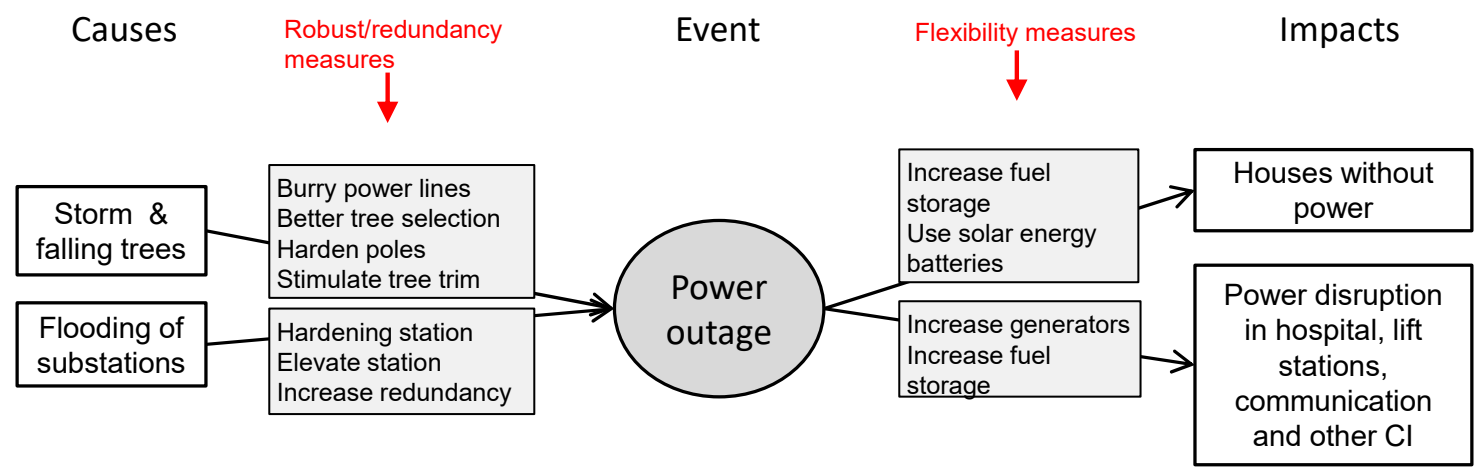

Figure 8. Electricity: causes, impacts, and potential measures which prevent power outages (in the grey blocks on the left side) or mitigate impacts (grey blocks on the right side).

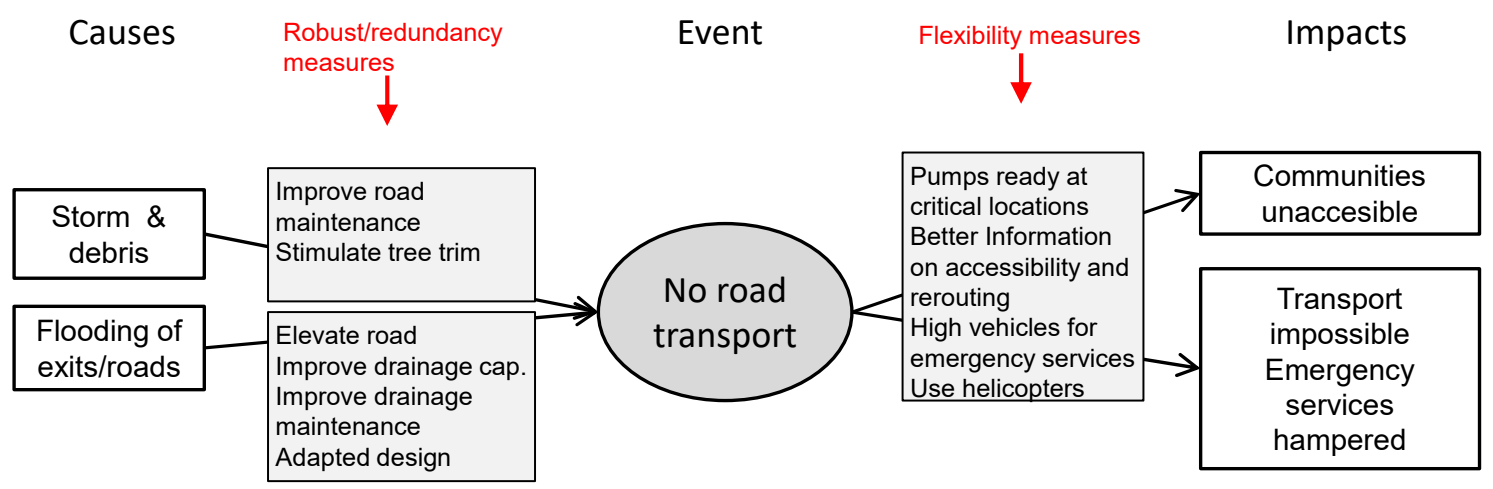

Figure 9. Road transport: causes, impacts, and potential measures which prevent disruption of road transport (in the grey blocks on the left side) or mitigate impacts (grey blocks on the right side).

After the workshops, the researchers used the resilience characteristics to check if all types of measures were considered: To increase robustness, measures such as elevating power stations, or protecting them by flood walls, or improving building codes and designs were mentioned. To increase redundancy, the importance of back generators was emphasized as well as the possibility of making roads accessible from multiple exits. Also, an additional fuel storage location in a less flood-prone area could be identified. To increase flexibility, emergency managers should have access to high vehicles, helicopters, and boats. Mobile backup generators may be made available quickly and information availability and distribution must be improved to allow better preparedness and more effective response during events.

Based on the identified measures, we performed a hypothetical analysis for this paper to illustrate the use of the indicators and curves. We did a "what if analysis" to illustrate the effect of the following measures on the resilience curve and indicators:

- Electricity: power transmission stations are raised (increase robustness) and power backups are made available for more days (flexibility/redundancy) to reduce the number of affected persons from 45,000 persons for 14 days to 5000 persons for 7 days; 
- Roads: roads are repaired faster and the most crucial exits are made more robust. This is assumed to reduce the number of affected persons after one day from 18,000 (during two days) to 9000 during one day.

- Drinking water plants are fully protected against flooding.

- Emergency management, financial systems, commercial facilities, and waste water and storm water are less likely to become disrupted and are recovered sooner since power and transport options are reduced and do not last as long. Losses reduce from 3 to 1 million person days.

If this could be realized, then the disruption days would reduce from almost 3 million to 1 million person days (see Table 4). Also, businesses would suffer less. Disruption there would reduce from $34 \%$ to $9 \%$ (see Figure 10).

Table 4. Disruption days in the new situation after implementing the measures with the abovementioned effect.

\begin{tabular}{cccc}
\hline CI & Affected & Duration & Product \\
\hline Power and communication & 5000 & 7 & 35,000 \\
\hline Roads & 180,000 & 1 & 180,000 \\
& 9000 & 1 & 9000 \\
\hline Financial & 54,000 & 7 & 378,000 \\
\hline \multirow{2}{*}{ Emergency and health } & 180,000 & 1 & 180,000 \\
\hline Drinking water & 18,000 & 3 & 54,000 \\
\hline Waste water & 0 & 3 & 0 \\
\hline Commercial & 9000 & 14 & 126,000 \\
\hline & 126,000 & 1 & 126,000 \\
\hline
\end{tabular}

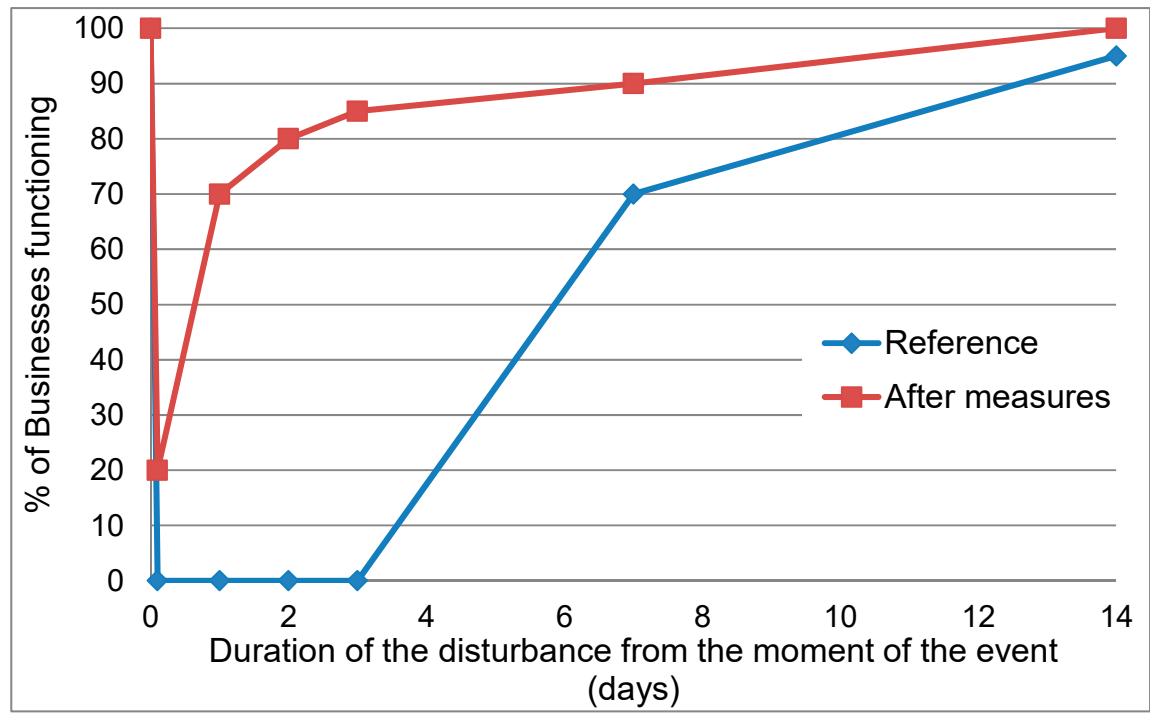

Figure 10. Businesses disruption before and after implementing measures.

\section{Discussion and Conclusions}

The paper presents an approach to assess the resilience of communities related to critical infrastructure failures due to flood hazards. The approach is meant to complement more common flood risk analyses. It is a participatory approach which aims to create a shared problem definition and vision on potential measures among local governments, emergency responders, and critical infrastructure owners and operators. Knowledge of critical infrastructure vulnerability and cascading effects is crucial 
for understanding how flood risks propagate across infrastructures and towards society. With the approach provided and the scenario-oriented discussions, knowledge from participating stakeholders is captured and shared, which may support decisions on the prioritization of measures. The analysis of various types of adaptation measures, increasing either robustness, redundancy, or flexibility and their effects, helps city planners to narrow down and strategize spatial flood management and urban development planning to improve the resilience of communities. The approach was applied to Fort Lauderdale in Broward County, Florida, United States, an area which was recently affected by floods and hurricanes.

The proposed resilience indicator and its values must be regarded with caution: they were based on the inputs of experts and stakeholders in workshops, the literature, and interviews, but they must be shared and validated before they can be considered reliable. Additional information on vulnerability thresholds of elements, outages, repair times, and the possibility of measures must be collected. The results presented here illustrate an approach to prioritize and focus the follow-ups and data collection. For a final selection of strategies and measures, further analyses are needed, such as cost-benefit analyses, societal acceptance, equity, and environmental criteria. This cannot be based on one future scenario and one rainfall event only. For that, the approach presented here needs to be linked to a risk analysis which analyzes all relevant events and their probabilities in various climate change scenarios.

The approach presented here, using tools and methods to structure workshops, helps to obtain an accepted strategy. However, its success strongly depends on the attendees of the workshops. It only functions well if the workshops are well prepared, the right persons are present, and if they recognize the scenario. In Fort Lauderdale, the storyline event may, in the minds of the attendees, have been mixed up with Hurricane Irma. In other areas, where no recent flood events have occurred, this will not be the case. A clear storyline is then more important. It must be relevant and realistic in order to support a decision.

The indicator "person disruption days" covers the impacts of critical infrastructure failure. However, as briefly touched upon, resilience covers much more. It also has to do with resourcefulness, governmental capacities, and, for example, equity. Here, we focused on those aspects which are specifically related to critical infrastructure resilience to floods. In fact, to become resilient, communities must also consider many additional aspects. These also help to resist, mitigate, and recover from floods or to adapt and learn to be able to better cope with flood hazards.

The approach here enables one to take into account time (before, during, and after an event) and to benefit from the knowledge and possible measures of a wide range of actors, which is a step from resilience quantification to using resilience as a guiding principle. In subsequent work, the outcomes will be discussed with the stakeholders and the step towards a more comprehensive combination with the risk approach will be targeted. Furthermore, a more detailed analysis for the most feasible measures is envisaged.

Author Contributions: K.M.d.B.: Conceptualization, methodology, writing, and investigation; J.O. and C.J.: investigation; A.B.: software; C.M., J.D., and M.Z.: validation.

Funding: The work presented here used the results of the CIFRe project (Critical Infrastructure and future Flood Resilience in South Florida). This research was funded by the NOAA SARP program, award number NA16OAR4310127.

Conflicts of Interest: The authors declare no conflicts of interest. 


\section{Appendix A Overview of Direct and Indirect Flood Impacts Related to Critical Infrastructure}

Table A1. Critical infrastructure thresholds for direct impacts, indirect flood impacts, and repair times.

\begin{tabular}{|c|c|c|c|c|}
\hline CI Service & Direct Effect from Floods & $\begin{array}{l}\text { Indirect Effects by } \\
\text { Disruptions in Other CI } \\
\text { Networks }\end{array}$ & Impact on Citizens & Repair Time [21] \\
\hline Power supply & $\begin{array}{l}\text { Transformation stations may } \\
\text { be flooded, failure if depth } \\
\text { exceeds } 30 \mathrm{~cm}(1 \mathrm{ft}) \text { is likely }\end{array}$ & $\begin{array}{l}\text { Roads: If roads are closed, } \\
\text { repairs may take more time, } \\
\text { and fuel for backup systems } \\
\text { may not be obtained. After } \\
2-4 \text { days, this may result in } \\
\text { problems }\end{array}$ & $\begin{array}{l}\text { No light, } \\
\text { air-conditioning, } \\
\text { power in homes and } \\
\text { businesses. Severe } \\
\text { business interruption } \\
\text { and reduced livability }\end{array}$ & $\begin{array}{l}\text { Up to } 4 \text { weeks, } \\
\text { most critical } \\
\text { services repaired } \\
\text { within days }\end{array}$ \\
\hline Road transport & $\begin{array}{l}\text { Roads may become blocked } \\
\text { by debris or fallen } \\
\text { poles/trees, exits may } \\
\text { become flooded. Roads } \\
\text { inaccessible if water depths } \\
>1 \mathrm{ft}\end{array}$ & $\begin{array}{l}\text { Power: Disruption will affect } \\
\text { signalling systems and cause } \\
\text { delays on roads }\end{array}$ & $\begin{array}{l}\text { Difficulties getting } \\
\text { food and supplies or } \\
\text { assistance, and to } \\
\text { repair damages; } \\
\text { business interruption }\end{array}$ & $\begin{array}{l}\text { Regional: first } 2 \\
\text { days, full network }\end{array}$ \\
\hline $\begin{array}{l}\text { Financial services } \\
\text { (cash machines) }\end{array}$ & - & $\begin{array}{l}\text { Power: If power is out, then } \\
\text { some will not function. Others } \\
\text { have backup power supply } \\
\text { systems. }\end{array}$ & $\begin{array}{l}\text { No cash, business } \\
\text { interruption }\end{array}$ & Days to 2 weeks \\
\hline Railroads & & $\begin{array}{l}\text { Power: Disruption will affect } \\
\text { signalling systems and cause } \\
\text { delays on roads }\end{array}$ & No transport by rail & Days \\
\hline Airport & $\begin{array}{l}\text { Landing lanes may become } \\
\text { flooded }\end{array}$ & $\begin{array}{l}\text { Power: Light, communication, } \\
\text { signalling, luggage control } \\
\text { Transport: If roads, railroads } \\
\text { do not function, then people, } \\
\text { goods, and personnel may not } \\
\text { reach the airport. } \\
\text { Harbor: People and goods may } \\
\text { not reach the airport if the } \\
\text { port is closed }\end{array}$ & $\begin{array}{l}\text { Difficult to evacuate } \\
\text { patients, tourists may } \\
\text { use other airfields and } \\
\text { ports, reputation } \\
\text { damage, loss of } \\
\text { business }\end{array}$ & About 3 days \\
\hline Harbor & $\begin{array}{l}\text { Parts of the port can become } \\
\text { flooded }\end{array}$ & $\begin{array}{l}\text { Power: Electric cranes, } \\
\text { signalling and electronic } \\
\text { controls are not functioning } \\
\text { Transport: If roads and } \\
\text { railroads are closed, no } \\
\text { supplies and people cannot } \\
\text { reach the port } \\
\text { Airport: If people cannot arrive } \\
\text { by plain, they will miss their } \\
\text { cruise ship }\end{array}$ & $\begin{array}{l}\text { Reputation damage, } \\
\text { loss of business }\end{array}$ & $\begin{array}{l}\text { Port closed for } \\
\text { about } 3 \text { days, } \\
\text { effects may last } \\
\text { longer. }\end{array}$ \\
\hline $\begin{array}{l}\text { Drinking water } \\
\text { supply }\end{array}$ & $\begin{array}{l}\text { Drinking water production } \\
\text { facilities may become } \\
\text { flooded if water depths } \\
\text { exceed } 30 \mathrm{~cm}(1 \mathrm{ft}) \text { and are } \\
\text { then contaminated }\end{array}$ & $\begin{array}{l}\text { Communication: Drinking } \\
\text { water has its own } \\
\text { communication system and is } \\
\text { not affected by } \\
\text { communication interruptions } \\
\text { Power: Drinking water has } \\
\text { backups for } 4-5 \text { days }\end{array}$ & $\begin{array}{l}\text { Reduced livability, } \\
\text { health risks }\end{array}$ & Several days \\
\hline $\begin{array}{l}\text { Waste water } \\
\text { system }\end{array}$ & $\begin{array}{l}\text { Some facilities can become } \\
\text { flooded, leading to outage } \\
\text { and contamination of the } \\
\text { surrounding areas }\end{array}$ & $\begin{array}{l}\text { Power: Not all lift stations } \\
\text { have backups; fuel for } 2 \text { days } \\
\text { Transport: Without transport, } \\
\text { fuel for the backup systems } \\
\text { cannot be reached } \\
\text { Communication: If wastewater } \\
\text { overflows cannot be } \\
\text { communicated, then no } \\
\text { measures can be taken }\end{array}$ & $\begin{array}{l}\text { Reduced livability, } \\
\text { health risks }\end{array}$ & Weeks \\
\hline
\end{tabular}


Table A1. Cont.

\begin{tabular}{|c|c|c|c|c|}
\hline CI Service & Direct Effect from Floods & $\begin{array}{l}\text { Indirect Effects by } \\
\text { Disruptions in Other CI } \\
\text { Networks }\end{array}$ & Impact on Citizens & Repair Time [21] \\
\hline $\begin{array}{l}\text { Communication } \\
\text { systems }\end{array}$ & No direct impacts expected & $\begin{array}{l}\text { Power supply: Without power, } \\
\text { the communication system } \\
\text { does not work } \\
\text { Transport: If roads are closed, } \\
\text { then no fuel for backup } \\
\text { systems can be brought in }\end{array}$ & $\begin{array}{l}\text { Slowdown of response, } \\
\text { impossibility of } \\
\text { reaching out for help, } \\
\text { lack of information } \\
\text { causing uncertainty } \\
\text { resulting in stress, } \\
\text { impossibility of } \\
\text { checking on the } \\
\text { well-being of relatives } \\
\text { and friends }\end{array}$ & $\begin{array}{l}2 \text { days to } 4 \text { weeks } \\
\text { (1 week) }\end{array}$ \\
\hline $\begin{array}{l}\text { Storm water } \\
\text { system }\end{array}$ & $\begin{array}{l}\text { Some facilities can become } \\
\text { flooded }\end{array}$ & $\begin{array}{l}\text { Power: Without power, pumps } \\
\text { do not operate; there are } \\
\text { fuelled backups for } 2-4 \text { days } \\
\text { Transport: Without transport, } \\
\text { fuel cannot be reached } \\
\text { Communication: Gates and } \\
\text { pumps cannot be controlled }\end{array}$ & $\begin{array}{l}\text { Additional flooding } \\
\text { locally }\end{array}$ & 2 days \\
\hline Emergency services & No direct effects expected & $\begin{array}{l}\text { Power, transport, and } \\
\text { communication: Without these, } \\
\text { emergency service operations } \\
\text { are hampered }\end{array}$ & $\begin{array}{l}\text { Delays or no rescue of } \\
\text { ill or wounded people; } \\
\text { uncertainty on status, } \\
\text { duration, and what to } \\
\text { do, which increases } \\
\text { stress }\end{array}$ & 1 week \\
\hline Health care & & $\begin{array}{l}\text { Transport: If roads are closed, } \\
\text { supplies, patients, and } \\
\text { personnel cannot reach the } \\
\text { hospital } \\
\text { Emergency services: If they do } \\
\text { not function well, patients } \\
\text { may not able to arrive } \\
\text { Drinking water: Without } \\
\text { drinking water, the hospital } \\
\text { cannot operate } \\
\text { Airport: Patients and supplies } \\
\text { cannot be transported by air } \\
\text { when needed } \\
\text { Power is only an issue when it is } \\
\text { out for more than } 5 \text { days. }\end{array}$ & $\begin{array}{l}\text { Dangerous situations } \\
\text { for patients and } \\
\text { wounded persons }\end{array}$ & Days \\
\hline $\begin{array}{l}\text { Commercial } \\
\text { facilities }\end{array}$ & $\begin{array}{l}\text { Some supermarkets and } \\
\text { other commercial facilities } \\
\text { are flood-prone }\end{array}$ & $\begin{array}{l}\text { Power: Without power, } \\
\text { supermarkets will be closed } \\
\text { Transport: People cannot reach } \\
\text { the supermarket } \\
\text { Financial services: If financial } \\
\text { services do not operate, } \\
\text { commercial services cannot } \\
\text { function }\end{array}$ & $\begin{array}{l}\text { Lack of food and } \\
\text { supplies }\end{array}$ & $\begin{array}{l}\text { Closed for } 3 \text { days, } \\
\text { effects lasting } \\
\text { longer }\end{array}$ \\
\hline
\end{tabular}

\section{References}

1. Hallegatte, S.; Green, C.; Nicholls, R.J.; Corfee-Morlot, J. Future flood losses in major coastal cities. Nat. Clim. Chang. 2013, 3, 802-806. [CrossRef]

2. Hirabayashi, Y.; Mahendran, R.; Koirala, S.; Konoshima, L.; Yamazaki, D.; Watanabe, S.; Kanae, S. Global flood risk under climate change. Nat. Clim. Chang. 2013, 3, 816-821. [CrossRef]

3. Winsemius, H.C.; Van Beek, L.P.H.; Jongman, B.; Ward, P.J.; Bouwman, A. A framework for global river flood risk assessments. Hydrol. Earth Syst. Sci. 2013, 17, 1871-1892. [CrossRef]

4. De Bruijn, K.M.; Buurman, J.; Mens, M.; Dahm, R.; Klijn, F. Resilience in practice: Five principles to enable societies to cope with extreme weather events. Environ. Sci. Policy 2017, 70, 21-30. [CrossRef]

5. Aerts, J.C.J.H.; Botzen, W.; Clarke, K.C.; Cutter, S.L.; Hall, J.W.; Merz, B.; Michel-Kerjan, E.; Mysiak, J.; Surminski, S.; Kunreuther, H. Integrating human behaviour dynamicss into flood disaster risk assessment. Nat. Clim. Chang. 2018, 8, 193-1999. [CrossRef]

6. Pant, R.; Thacker, S.; Hall, J.W.; Alderson, D.; Barr, S. Critical infrastructure impact assessment due to flood exposure. J. Flood Risk Manag. 2018, 11, 22-33. [CrossRef] 
7. Pitt, M. The Pitt Review_Learning Lessons from the 2007 Floods; Cabinet Office: London, UK, 2008. Available online: http://archive.cabinetoffice.gov.uk/pittreview/thepittreview/final_report.html (accessed on 1 February 2019).

8. McBain, W.; Wilkdes, D.; Retter, M. Flood Resilience and Resistance for Critical Infrastructure; CIRIA C688; CIRIA: London, UK, 2010.

9. De Bruijn, K.M.; Cumiskey, L.; Dhubhda, R.N.; Hounjet, M.; Hynes, W. Flood vulnerability of critical infrastructure in Cork, Ireland. In E3S Web of Conferences; EDP Sciences: Les Ulis, France, 2016; Volume 7, p. 7005.

10. Kalantari, Z.; Nickman, A.; Lyon, S.W.; Olofsson, B.; Folkeson, L. A method for fmapping flood hazard along roads. J. Environ. Manag. 2014, 133, 69-77. [CrossRef] [PubMed]

11. De Bruijn, K.M.; van der Most, H.; Cumiskey, L.; Hounjet, M.; Mens, M. Methods and Tools Supporting Urban Resilience Planning: Experiences from Cork, Ireland. J. Geosci. Environ. Prot. 2018, 6, 290. [CrossRef]

12. UNISDR (United Nations International Strategy for Disaster Reduction). Sendai Framework for Disaster Risk Reduction 2015-2030; UNISDR: Geneva, Switzerland, 2015. Available online: http:/ /www.unisdr.org/files / 43291_sendaiframeworkfordrren.pdf (accessed on 20 April 2015).

13. Burzel, A.; Hounjet, M.; Becker, B.; Di Pietro, A.; Pollino, M.; Rosato, V.; Tofani, A. Towards a Decision Support System for Consequence Analysis of Flooding on Critical Infrastructure. In Proceedings of the 11th International Conference on Hydroinformatics, New York, NY, USA, 17-21 August 2014.

14. De Bruijn, K.M.; Lips, N.; Gersonius, B.; Middelkoop, H. The storyline approach: a new way to analyse and improve flood event management. Nat. Hazards 2016, 81, 99-121. [CrossRef]

15. De Dianous, V.; Fiévez, C.L. ARAMIS project: A more explicit demonstration of risk control through the use of bow-tie diagrams and the evaluation of safety barrier performance. J. Hazard. Mater. 2006, 130, 220-233. [CrossRef] [PubMed]

16. Béné, C.; Cannon, T.; Gupte, J.; Mehta, L.; Tanner, T. Exploring the Potential and Limits of the Resilience Agenda in Rapidly Urbanising Contexts. Evidence Report 63; Policy Anticipation, Response and Evaluation; Institute of Development Studies: East Sussex, UK, 2014.

17. Folke. Resilience thinking: Integrating resilience, adaptability and transformability. Ecol. Soc. 2010, 15, 20. [CrossRef]

18. Sharifi, A.; Yamagata, Y. Urban Resilience Assessment: Multiple Dimensions, Criteria, and Indicators. In Urban Resilience; Springer: Cham, Switzerland, 2016. Available online: https:/ / www.researchgate.net/ publication/306016491_Urban_Resilience_Assessment_Multiple_Dimensions_Criteria_and_Indicators (accessed on 3 January 2019). [CrossRef]

19. Murdock, H.J.; De Bruijn, K.M.; Gersonius, B. Assessment of Critical Infrastructure Resilience to Flooding Using a Response Curve Approach. Sustainability 2018, 10, 3470. [CrossRef]

20. ARUP. City Resilience Framework; ARUP: London, UK, 2015.

21. Anonymous. Critical Infrastructure Networks of Broward County. Assessing Relationships and Exploring Adaptation and Mitigation Measures in Participatory Stakeholder Workshops; CIfre Project Report; Deltares Inc.: Silver Spring, MD, USA, 2018. Available online: http:// circle-cifre.nl/downloads/Overall\%20workshop\%20report\% 20CIFRe\%20project.pdf (accessed on 1 February 2019).

22. Weblink Circle. Available online: http:/ / circle.deltares.org (accessed on 1 February 2019).

23. CGERISK. Available online: https://www.cgerisk.com/knowledgebase/The_history_of_bowtie (accessed on 30 October 2018).

24. De Ruijter, A.; Guldenmund, F. The bowtie method: A review. Saf. Sci. 2016, 88. [CrossRef]

25. Weblink Intact. Available online: http://scm.ulster.ac.uk/ \{\}scmresearch/intact/index.php/Bow_tie_ analysis (accessed on 3 January 2019).

26. Weblink. Available online: https://www.fortlauderdale.gov/government/about-fort-lauderdale (accessed on 26 November 2018).

27. Weblink. Available online: https://nl.wikipedia.org/wiki/Fort_Lauderdale (accessed on 24 September 2018).

28. Federal Emergency Management Agency. Flood Insurance Study. Available online: https://fris.nc.gov/fris_ hardfiles/FL/FIS/12011CV000A.pdf (accessed on 1 February 2019).

29. FSU Data Weblink. Available online: https:/ / www.coaps.fsu.edu/data (accessed on 1 November 2017).

30. Anonymous. Assessment of Available Tools to Create a More Resilient Transportation System, Final Report for Resolution R-235-16; Directive 160220; Miami Dade County: Miami, FL, USA, 2016. 
31. SFWMD. South Florida Water Management District's Environmental Resource Permit Applicant's Handbook; SFWMD: West Palm Beach, FL, USA, 1 October 2013; Volume 11.

32. Decker, J.D.; Hughes, J.D.; Swain, E.D. Potential for Increased Inundation in Flood Prone Regions of South Florida in Response to Climate and Sea-Level Changes in Broward County, FL, 2060-2069; United States Geological Survey Scientific Investigations Report; U.S. Geological Survey: Reston, VA, USA, 2019.

33. Weblink. Available online: http://www.broward.org/Hurricane/Documents/EmergencyChecklists.pdf (accessed on 28 September 2018).

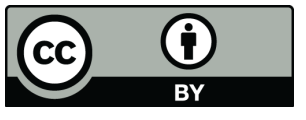

(C) 2019 by the authors. Licensee MDPI, Basel, Switzerland. This article is an open access article distributed under the terms and conditions of the Creative Commons Attribution (CC BY) license (http:/ / creativecommons.org/licenses/by/4.0/). 